\title{
Grass shrimp Palaemonetes pugio predation on sediment- and stem-dwelling meiofauna: field and laboratory experiments
}

\author{
Christopher S. Gregg*, John W. Fleeger \\ Department of Zoology, Louisiana State University, Baton Rouge, Louisiana 70803-1725, USA
}

\begin{abstract}
Field and laboratory experiments were conducted to clarify the predatory role of Palaemonetes pugio Holthius in salt-marsh benthic communities. Field experiments (cage enclosures using $P$. pugio as a predator) were conducted on unvegetated mudflat and vegetated-marsh sites. Neither sediment- or stem-dwelling meiofaunal abundances were significantly impacted. Laboratory experiments measured the functional response of $P$. pugio feeding on suspended harpacticoid copepods, tested the efficiency of $P$. pugio feeding on harpacticoids in sediments, and measured the predation rate of $P$. pugio on stem-dwelling meiofauna. Grass shrimp feeding rate on suspended copepods followed a type II functional response, increasing with increasing prey density to a maximum of 59 copepods $\mathrm{h}^{-1}$. When a sediment refuge was available, a $40 \%$ decline in the consumption of copepods by $P$. pugio was noted; this decreased feeding efficiency may contribute to the lack of significant declines in meiofaunal abundances in field enclosures over unvegetated sediment. $P$. pugio proved to be a highly effective predator on the fauna of Spartina alterniflora stems, significantly reducing abundances of stem-associated meiofauna within $24 \mathrm{~h}$ and consuming an estimated 35 meiofauna $\mathrm{h}^{-1}$ The greatest impact was exhibited on the lowest $(0$ to $6 \mathrm{~cm}$ ) portion of the stems. These experiments suggest that laboratory experiments are an important aid to help interpret field experiments examining predation on meiofauna, and that Spartina stems, and their epiphytic algae and meiofauna, are important, but largely overlooked, resources in salt-marsh food webs.
\end{abstract}

KEY WORDS: Palaemonetes pugio - Salt marsh - Predation - Meiofauna - Spartina alterniflora stems . Functional response

\section{INTRODUCTION}

Evidence that epibenthic predators can regulate meiofaunal assemblages was first implicated in experimental studies by Bell \& Coull (1978). Subsequently, many studies have quantified the effect of epibenthic predators on meiofauna. Experiments using exclosures in salt-marsh (Bell 1980, Fleeger 1985) and shallow muddy sites (Olafsson \& Moore 1990, 1992) demonstrated that meiofaunal densities often increase in the absence of epibenthic predators, presumably due to a release from predation. Other experiments utilizing predator enclosures and laboratory mesocosms indi-

\footnotetext{
- Present address: Institute of Marine and Coastal Sciences, Rutgers, The State University of New Jersey, 71 Dudley Rd, New Brunswick, New Jersey 08901-8521, USA.

E-mail: cgregg@imcs.rutgers.edu
}

cate that fish and crustaceans reduce meiofaunal abundances (Gee et al. 1985, Smith \& Coull 1987, Gee 1987, Ellis \& Coull 1989, Nilsson et al. 1993, Coull et al. $1995)$ and alter vertical distribution in sediments (Fitzhugh \& Fleeger 1985, Coull et al. 1989, HedquistJohnson \& Andre 1991). While sediment-dwelling meiofauna in salt marshes have been well studied, the small macro- and meiofauna inhabiting the stems of marsh vegetation have, until recently, been an overlooked component of the biota of marshes. Large populations have been reported living within the stem sheath and vascular tissue of Spartina alterniflora and on its epiphyte growth (Burke 1976, Van Dolah 1978, Rutledge \& Fleeger 1993, Heally \& Walters 1994), and densities on stems rival those of adjacent sediments (Rutledge \& Fleeger 1993). Walters et al. (1996) showed that fish and crustaceans are able to significantly reduce the densities of meiofauna living on S. alterniflora stems. 
Field exclusion/inclusion experiments are open to many criticisms (Virnstein 1978, Peterson 1979, Olafsson et al. 1994), usually intrinsic to the cage itself (e.g. alterations in hydrodynamics, larval settlement patterns). Nevertheless, additional concerns about the interpretation of the results of exclusion/inclusion experiments should be raised. For example, predation rates on suspected prey are seldom known, making it impossible to compare prey decreases inside enclosures or increases inside exclosures with those expected due to predation. Functional responses of benthic predators have generally not been examined (but see Lipcius \& Hines 1986), and little is known about differences in predation rate among habitats. Field exclusion/inclusion experiments remain one of the best ways of examining predator impacts on benthos, but they might be strengthened if appropriate corroborative laboratory experiments were available.

A number of studies have examined Palaemonetes pugio Holthius effects on salt-marsh fauna, with inconsistent results (Bell \& Coull 1978, Kneib 1985, Smith \& Coull 1987, Walters et al. 1996). The purpose of this research was to refine our understanding of how $P$. pugio impacts meiofaunal communities in a Louisiana salt marsh. First, field enclosure experiments were conducted to determine how grass shrimp affect prey assemblages at 2 study sites; an unvegetated mudflat and a vegetated-marsh site. Second, to better interpret field studies, we described the functional response of grass shrimp feeding on suspended meiobenthic copepods, a common prey item in estuarine food webs. Finally, laboratory experiments were done under conditions that mimicked specific habitats (unvegetated sediments and Spartina alterniflora stems) to determine the capacity of $P$. pugio to reduce prey populations. The results of all these experiments were synthesized and used to test the null hypothesis that predation impacts by $P$. pugio do not differ between infaunal and stem habitats.

\section{MATERIALS AND METHODS}

Sediment-enclosure experiment. The experiment was carried out from July 6 to 11, 1994, at a site near Port Fourchon, Louisiana, USA, adjacent to Bay Champaign, near the Louisiana Universities Marine Consortium (LUMCON) Laboratory (29 $10^{\prime} \mathrm{N}, 90^{\circ} 10^{\prime} \mathrm{W}$ ). The sediment-enclosure experiment was designed to test for an effect of Palaemonetes pugio on meiofauna in shallow subtidal sediments. The experiment consisted of 3 treatments: a shrimp enclosure cage, a partialcage control, and a no-cage-control area. The cages were constructed from rectangular, clear polycarbonate sheets $(1.25 \mathrm{~m} \times 0.75 \mathrm{~m})$ formed into a cylinder (basal area $=0.44 \mathrm{~m}^{2}$ ) by bolting the ends together Fourteen portholes $(10 \mathrm{~cm}$ diameter) were covered with $1 \mathrm{~mm}$ mesh screen to prevent nekton and macroepibenthic predators from entering or leaving the cages. Mesh screens were not placed over the portholes of the partial-cage controls, to permit free exchange of nekton and macrofauna into enclosures. Nearby undisturbed cageless-control areas of the same size were marked with stakes. Treatments were arranged in a randomized design determined a priori with 6 replications. Sediment granulometry at this site ranged from 83 to $96 \%$ silt clay, and the organic content was $9.4 \%( \pm 0.68 \mathrm{SD})$.

Cages were gently pushed approximately 15 to $20 \mathrm{~cm}$ into the sediment. Roughly 100 grass shrimp were put into the enclosure cages after placement. This density (225 shrimp $\mathrm{m}^{-2}$ ) was approximately 3 times the mean reported from the area by Hayden (1994). Grass shrimp, collected in an area adjacent to the study site, were captured by seining on the day before placement of the cages and were kept in a large aerated holding tank to minimize stress.

After $5 \mathrm{~d}$, each experimental unit was sampled for sediment-dwelling meiofauna using a $5.31 \mathrm{~cm}^{2}$ corer. Three cores were taken from each experimental unit, and the top $1 \mathrm{~cm}$ of sediments from each core was fixed with $10 \%$ buffered formalin, and stained with rose bengal. Samples were processed by sieving the sediment through $500 \mu \mathrm{m}$ and $63 \mu \mathrm{m}$ nested sieves. The material retained on the $63 \mu \mathrm{m}$ sieve was separated from sediments using the Ludox $\mathrm{AM}^{\otimes}$ extraction technique of Fleeger \& Chandler (1983). The efficiency of the extraction was estimated to be $95 \%$ (from counts of pellets). Individuals from the supernatant fraction were sorted to major taxon and enumerated to estimate densities of meiofauna and small macrofauna. The material retained on the $500 \mu \mathrm{m}$ sieve was examined for small macrofauna.

Data were analyzed with multivariate analysis of variance (MANOVA) in SAS (1985) to examine experiment-wide results with response variables being the major taxonomic groups. Response variables consisted of those taxa found in $>50 \%$ of all samples. The analysis entailed a nested randomized design that included treatment and the samples taken from each replicate in the model. Homogeneity of variances and normality of the data were tested, and a $\ln (x+1)$ transformation was used to normalize data

Stem-enclosure experiment. To determine if grass shrimp affected the small macro- and meiofauna inhabiting the stems of the salt-marsh cord grass Spartina alterniflora, an experiment was conducted from October 7 to 11, 1994, at a shallow intertidal area near the site of the sediment-enclosure experiment. Treatments were the same as those in the previous experiment. 
The selected area was in the low intertidal marsh below the natural stream-side levee with $S$. alterniflora plants approximately $65 \mathrm{~cm}$ in height and in densities of 321 stems $\mathrm{m}^{-2}$. Four locations were chosen that were at approximately the same elevation relative to the low-tide mark and 1 replicate of each treatment was randomly placed at each location. After cages were placed at the predetermined sites and were filled at high tide, approximately 100 grass shrimp were gently added to the enclosures.

After $7 \mathrm{~d}$, Spartina alterniflora stems were sampled from each experimental unit by gently pulling the stems out of the sediment and clipping them at $6 \mathrm{~cm}$ intervals (i.e. $0-6,6-12$, and $12-18 \mathrm{~cm}$ ) beginning at the point where the stem emerged from the sediment. The clipped stems were then placed into a $7 \%$ solution of magnesium chloride to narcotize the fauna and facilitate their removal. Then, samples were transferred to $10 \%$ buffered formalin and stained with rose bengal.

Samples were processed by thoroughly washing the stems over nested $500 \mu \mathrm{m}$ and $63 \mu \mathrm{m}$ sieves and gently grating the stems on the $500 \mu \mathrm{m}$ sieve to ensure the removal of all fauna. Individuals retained on both sieves were counted and sorted to major taxon. Abundances of meiofauna per stem were transformed to number per $100 \mathrm{~cm}^{2}$ (sensu Rutledge \& Fleeger 1993) by measuring the diameter of the stem section and calculating the surface area as if the stem were a cylinder. Because some harpacticoid copepods are adapted to live within the vascular tissue of Spartina alterniflora (Leptocaris brevicornis, and unidentified species in the family Ameiridae and Diosaccidae; see Rutledge \& Fleeger 1993), copepods that were vermiform (sensu Coull 1977, Bell et al. 1987) in shape were enumerated separately. It was assumed that these species inhabited the inside of the stem sheaths and were not susceptible to predation. Subsequent analysis, using only 'noninterstitial' copepods, was performed on copepod densities over the bottom $18 \mathrm{~cm}$ of $S$. alterniflora stems.

Data were analyzed using MANOVA in SAS (1985) to examine experiment-wide results over the bottom $18 \mathrm{~cm}$ of stems. The analysis consisted of a randomized block design (location of enclosures as blocks) with treatment, stem sections, and their interactions in the model. Homogeneity of variance and normality tests were conducted, and a $\ln (x+1)$ transformation was used to meet these assumptions.

Functional response. The functional response of grass shrimp feeding on meiobenthic, harpacticoid copepods dispersed in the water column was measured in 41 beakers used as predation arenas. One grass shrimp (starved for 24 h) was added to each beaker that contained $2000 \mathrm{ml}$ artificial sea water $(25 \%)$. Shrimp were allowed to feed for $1 \mathrm{~h}$ on known numbers of prey, previously enumerated with a dissecting microscope.
Amphiascoides atopus Lotufo \& Fleeger, obtained from a laboratory mass culture (Sun \& Fleeger 1995), was used as prey. A. atopus is an epibenthic harpacticoid copepod that makes frequent forays into the water column before returning to the bottom. After $1 \mathrm{~h}$, the contents of each beaker were sieved through a $63 \mu \mathrm{m}$ sieve, fixed in $10 \%$ buffered formalin, and stained with rose bengal. The remaining prey were enumerated and prey consumed estimated by subtraction. These experiments were repeated, offering increasing densities of prey (from 20 to 200) until an upper asymptote was reached. Each prey-density treatment was replicated 4 times and the mean number consumed in each treatment calculated and plotted against initial prey density. Experiments were conducted in the dark because $A$. atopus strongly aggregates to avoid light (Sun $\&$ Fleeger 1995). As a test of counting/recovery efficiency, 4 replications were conducted as controls with no shrimp added, and the recovery of copepods averaged $99 \%$.

The shape of the functional response curve was determined by performing a logistic regression, using the CATMOD procedure in SAS (1985), of the proportion of prey eaten vs number of prey present (Trexler et al. 1988, Juliano 1993). This method was used because it is easier to distinguish between type II and type III functional responses using plots of the proportion of prey consumed vs number of prey present. A functional-response model was then fit to the data using non-linear least-squares regression, in SAS.

Feeding efficiency in sediments. This experiment was designed to determine if sediment altered the ability of Palaemonetes pugio to consume meiobenthic copepods. Two treatments, with 4 replicates of each treatment, were used in the experiment: predation arenas with a $1 \mathrm{~cm}$ layer of sediment covering the bottom and arenas with no added sediment. Predation arenas consisted of $4 \mathrm{l}$ beakers, containing $1500 \mathrm{ml}$ artificial sea water $(25 \%)$ ). Two hours before the experiment, azoic sediment was added to the sediment treatments and allowed to settle. Then, 100 harpacticoid copepods, collected from muddy sediments by sieving, were added to the beakers and allowed to acclimate for $1 \mathrm{~h}$. These copepods are mostly epibenthic and readily reenter sediment after extraction (Decho \& Fleeger 1988, Fleeger et al. 1995). At the end of this time, one grass shrimp, starved for $24 \mathrm{~h}$, was added to each beaker and allowed to feed for $45 \mathrm{~min}$. The contents of the beakers were then captured on a $63 \mu \mathrm{m}$ sieve and preserved in $10 \%$ buffered formalin. Copepods remaining were enumerated to determine the number consumed. Four replicates of each treatment were conducted as above without shrimp as a test of recovery and counting efficiency; $99 \%$ of the copepods added were recovered from controls. A Student's $t$-test was 
employed to determine if there were significant differences between sediment and non-sediment treatments. Normality and homogeneity of variance tests suggested that data transformation was not necessary.

Stem-predation experiment. The stem-predation experiment was designed to determine if Palaemonetes pugio affected meiofauna living on Spartina alterniflora stems in a controlled laboratory setting. Two treatments were used in this experiment: one with $P$. pugio added to microcosms and a control without shrimp. Microcosms consisted of $40 \mathrm{l}$ aquaria into which $S$. alterniflora stems were added in densities comparable with those measured in the field ( 30 stems aquarium $^{-1}, 321.1$ stems $\mathrm{m}^{-2}$ ). The aquaria were filled with filtered $(45 \mu \mathrm{m})$ sea water $(22 \%)$ to $10 \mathrm{~cm}$ in depth, and $3 \mathrm{~cm}$ of azoic, commercial play sand was used as a substrate to hold the stems in place. Walters et al. (1996) observed that meiofauna inhabiting $S$. alterniflora stems show little tendency to migrate to this type of substrate. An aquarium air pump was used for aeration. The experiment included 10 microcosms in all, with 5 replications of each treatment arranged in a randomized design. Salinity (with refractometer), temperature, and oxygen (with a dissolved-oxygen meter) were measured on Days 1 and 2.

Spartina alterniflora stems were harvested on Day 1 , from a low-marsh habitat, by removing culms from the sediments, then separating individual stems and trimming away most of the root mat from the base. The stems were then placed in experimental aquaria by pushing them into sand just far enough to remain upright. The microcosms were left undisturbed for $15 \mathrm{~h}$ before adding grass shrimp to the microcosms on Day 2. Shrimp were added at densities twice the mean for the area as reported by Hayden (1994) (15 shrimp aquarium $^{-1}=120$ shrimp $\mathrm{m}^{-2}$ ), and were left in the microcosms for $24 \mathrm{~h}$.

Upon completion of the experiment, 5 stems were sampled from each microcosm by gently pulling them from the substrate and clipping them at $6 \mathrm{~cm}$ intervals from their base. To ensure that only meiofauna exposed to grass shrimp predation were enumerated, a twist tie was wrapped around each section to keep the sheath tightly attached to the stem. The stems were fixed in $10 \%$ buffered formalin and stained with rose bengal. Stems were processed by washing on a $63 \mu \mathrm{m}$ sieve with the twist tie still in place to assure that only the meiofauna inhabiting the outside of the stem sheath were removed, eliminating the need to distinguish between 'interstitial' and 'noninterstitial' copepods. Individuals retained on the sieve were sorted to major taxon and counted to determine meiofaunal density on the outside of Spartina alterniflora stem sheaths. Qualitative sediment samples were also taken from the microcosms to determine if meiofauna colonized sediments from the stems, and the water remaining in the aquaria was pumped through a $63 \mu \mathrm{m}$ sieve to determine if migration took place.

Data were analyzed using MANOVA with a nested model to examine experiment-wide results. The analysis consisted of a randomized design that included treatment and the individual stems taken from each replicate in the model. This analysis was performed on abundance data from the lowest $12 \mathrm{~cm}$ of stems and data from each $6 \mathrm{~cm}$ section. Nematodes, copepods, and copepod nauplii were the response variables tested in the model. Other taxa included polychaetes, isopods, amphipods, tanaids, and mites; however, these taxa were not abundant enough to be considered individually in the analysis. Homogeneity of variance and normality tests suggested that data transformation was not necessary.

\section{RESULTS}

\section{Sediment-enclosure experiment}

Nematodes were the most abundant of the major infaunal groups sampled, constituting $90 \%$ of the meiofauna and averaging 1103 ind. per $10 \mathrm{~cm}^{2}$ in all treatments combined (Table 1 ). Copepod nauplii (68 per 10 $\mathrm{cm}^{2}$ ) and copepods (46 per $10 \mathrm{~cm}^{2}$ ) were the second and third most abundant taxon, making up 5\% and $3 \%$ of the meiofauna respectively; polychaetes ( 9 ind. per $10 \mathrm{~cm}^{2}$ ) made up about $0.7 \%$ of the meiofauna. Other taxa included turbellarians, ostracods, amphipods, bivalves, gastropods, and oligochaetes, but these comprised $<1 \%$ of the fauna collected (none were included in further analysis).

Densities of the taxonomic groups sampled were similar across all experimental treatments. No treatment effect was detected using MANOVA on densities
Table 1. Mean number of meiofaunal taxa ( \pm SEM) sampled from experimental treatments in sediment-enclosure experiment and overall mean with percent composition of each taxon from all treatments. Values are reported as the number of individuals per $10 \mathrm{~cm}^{2} \mathrm{NCC}$ : non-cage control; PCC: partial-cage control ENC: shrimp enclosure

\begin{tabular}{|lcccrc|}
\hline Taxon & \multicolumn{5}{c}{ Treatment } \\
& NCC & PCC & ENC & Mean & $\%$ \\
\hline Nematoda & $1062(147.1)$ & $1060(160.8)$ & $1189(139.3)$ & 1103 & 90 \\
Copepoda & $41(5.0)$ & $32(4.0)$ & $64(1.0 .8)$ & 46 & 3.7 \\
Nauplij & $66(11.6)$ & $50(7.9)$ & $87(22.7)$ & 68 & 5.5 \\
Polychaeta & $10(1.5)$ & $8(1.3)$ & $8(2.2)$ & 9 & 0.73 \\
\hline
\end{tabular}


of the major faunal groups over the $5 \mathrm{~d}$ experiment (Wilks $\lambda=0.499, F_{14,54}=1.60, p=0.11$ ). Subsequent univariate tests indicated no significant differences among treatments in the number of nematodes $(F=$ $0.39, p=0.68)$, copepod nauplii $(F=0.55, p=0.59)$, and polychaetes $(F=1.43, p=0.27)$. There was a marginal indication of higher copepod density in grass shrimp enclosures ( $F=3.00, \mathrm{p}=0.07$ ). These data suggest that grass shrimp were unable to effectively reduce sediment-dwelling meiofaunal densities in enclosures.

\section{Stem-enclosure experiment}

Nematodes were the most abundant taxon, making up $40 \%$ of the stem-dwelling fauna and averaging 1335 per $100 \mathrm{~cm}^{2}$ across treatments (Table 2). Copepods ( 796 per $100 \mathrm{~cm}^{2}$ ) and copepod nauplii (530 per $100 \mathrm{~cm}^{2}$ ) were the second and third most abundant taxa sampled, comprising $24 \%$ and $18 \%$ of the stemdwelling fauna, and polychaetes made up $2 \%$ of the fauna (68 per $100 \mathrm{~cm}^{2}$ ) (Table 2). Other taxa (amphipods, isopods, oligochaetes, and tanaids) made up $<1 \%$ of the fauna. Meiofauna were highest in abundance on the lower $12 \mathrm{~cm}$ of Spartina alterniflora stems (nematodes: $0-6 \mathrm{~cm}=56 \%, 6-12 \mathrm{~cm}=36 \%$; copepods: $0-6 \mathrm{~cm}=49 \%, 6-12 \mathrm{~cm}=39 \%$; copepod nauplii: $0-6$ $\mathrm{cm}=45 \%, 6-12 \mathrm{~cm}=38 \%$; polychaetes: $0-6 \mathrm{~cm}=$ $76 \%, 6-12 \mathrm{~cm}=23 \%$ ) with the highest percentages found on the 0-6 cm section.

No significant treatment effects were noted in the results of the MANOVA over the lower $18 \mathrm{~cm}$ of Spartina alterniflora stems $\left(\lambda=0.798, F_{12,168}=1.67, p=\right.$ $0.077)$. There were significant block effects noted for all taxa $\left(\lambda=0.616, F_{18,238}=2.47, \mathrm{p}=0.0011\right)$; MANOVA also showed that abundances of all taxa differed with stem section $\left(\lambda=0.251, F_{12.168}=13.9, \mathrm{p} \leq 0.0001\right)$ with significantly higher densities found on the lower stem sections

Table 2. Mean number of meiofaunal taxa ( \pm SEM) sampled from experimental treatments in stem-enclosure experiment with overall mean and percent composition of each taxon. Values are reported as the number of individuals per $100 \mathrm{~cm}^{2}$. NCC: non-cage control; PCC: partial-cage control; ENC: shrimp enclosure; Int: interstitial; NI: non-interstitial

\begin{tabular}{|c|c|c|c|c|c|}
\hline Taxon & $\mathrm{NCC}$ & $\begin{array}{l}\text { Treatment } \\
\text { PCC }\end{array}$ & ENC & Mean & $\%$ \\
\hline Nematoda & $1442(316.0)$ & $1333(263.3)$ & $1239(190.5)$ & 1335 & 49 \\
\hline Copepoda & $644(116.4)$ & $1056(168.3)$ & $703(114.3)$ & 796 & 29 \\
\hline Int Copepoda & $171(27.0)$ & $288(87.5)$ & $137(19.2)$ & 199 & $7^{a}$ \\
\hline NI Copepoda & $481(107.8)$ & $767(157.4)$ & $567(110.8)$ & 600 & $22^{4}$ \\
\hline Nauplii & $414(65.8)$ & $678(110.0)$ & $509(72.8)$ & 530 & 19 \\
\hline Polychaeta & $112(49.1)$ & $60(26.3)$ & $34(8.4)$ & 68 & 2 \\
\hline
\end{tabular}

Although the MANOVA examining treatment effects was not significant, we examined the effect of grass shrimp on non-interstitial copepod vertical distribution because the results of the stem predation experiment (see below) indicated that shrimp predation pressure is highest in the lowest stem sections. Copepod densities on the $0-6 \mathrm{~cm}$ sections were lowest in shrimp enclosures, 538 per $100 \mathrm{~cm}^{2}$ stem ( $\left.\pm 250 \mathrm{SEM}\right)$, and very similar in the partial-cage controls and no-cage controls (753 \pm 254 and $767 \pm 269$ per $100 \mathrm{~cm}^{2}$ stem respectively), but were highest on the $6-12 \mathrm{~cm}$ sections in shrimp enclosures $\left(693 \pm 271\right.$ per $100 \mathrm{~cm}^{2}$ stem) and again similar in the partial-cage controls and no-cage controls $\left(576 \pm 223\right.$ and $474 \pm 185$ per $100 \mathrm{~cm}^{2}$ stem respectively). ANOVAs were conducted on each stem section separately, but were not significant $(0-6 \mathrm{~cm}$ : $F=4.45, \mathrm{p}=0.065 ; 6-12 \mathrm{~cm}: F=0.44, \mathrm{p}>0.10)$.

\section{Functional response}

Palaemonetes pugio exhibited a type II functional response curve feeding on the harpacticoid copepod Amphiascoides atopus dispersed in the water column (Fig. 1). Estimates of both the linear $(-0.00557)$ and quadratic $(-0.00014)$ model terms obtained by logistic regression exhibited a constant decrease in the proportion of prey eaten by grass shrimp with increasing density of prey and the relation was best described by an Ivlev (1961) type II functional response equation

$$
N_{\mathrm{e}}=I_{\mathrm{m}}\left(1-\mathrm{e}^{-k N_{\mathrm{o}}}\right)
$$

$\left(\mathrm{r}^{2}=0.92, \mathrm{p}=0.0001\right)$ (Fig. 1). The model included the following variables: $N_{0}=$ the number of prey offered and $N_{e}=$ the number of prey consumed; the model also contained these parameters: $I_{\mathrm{m}}=$ the maximumingestion rate of the predator and $k=$ a proportionality constant. $I_{\mathrm{m}}$ and $k$ were estimated using the Marquardt nonlinear least squares iterative algorithm with $I_{\mathrm{m}}=59.19$ copepods consumed $\mathrm{h}^{-1}$ and $\mathrm{k}=$ 0.022 .

\section{Feeding efficiency in sediments}

A sediment refuge reduced the consumption rate of Palaemonetes pugio on meiobenthic copepods by $40 \%$ (Fig. 2). Grass shrimp consumed significantly fewer copepods when prey were allowed to burrow into sediments compared to those dispersed in the water column $(t=-2.86$, $p=0.0289$ ). Predation rate averaged 50 copepods $\mathrm{h}^{-1}$ without sediment, but only 20 copepods $h^{-1}$ with sediment present. 


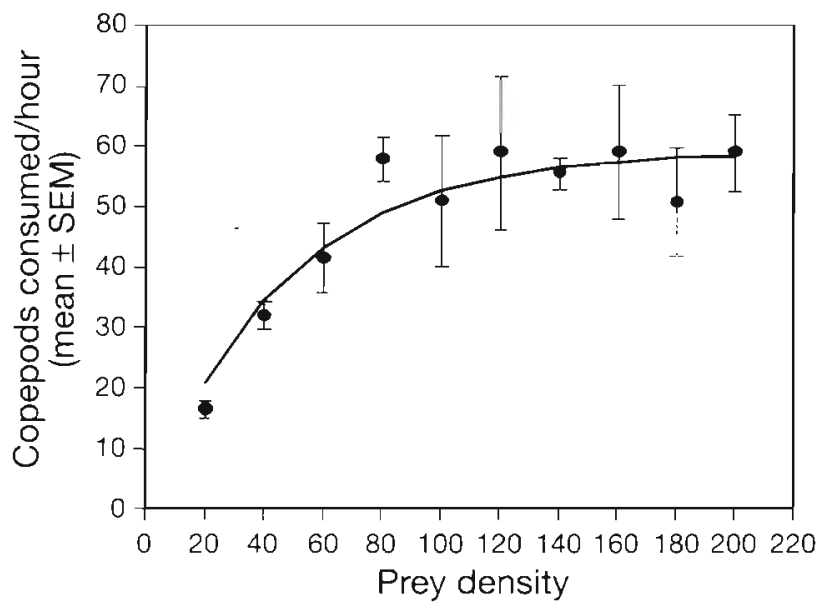

Fig. 1. Type II functional response curve, using Ivlev's (1961) equation $N_{\mathrm{e}}=I_{\mathrm{m}}\left[1-\exp \left(-k N_{\mathrm{o}}\right)\right]$, for grass shrimp feeding on Amphiascoides atopus, where $N_{\mathrm{o}}=$ number of prey offered, $N_{\mathrm{e}}=$ number of prey eaten, $I_{\mathrm{m}}=$ maximum ingestion rate, $k=$ constant

\section{Stem-predation experiment}

The mean oxygen levels for no-shrimp treatments on Day 1 were $7.54 \mathrm{mg} \mathrm{O}_{2} \mathrm{l}^{-1}$ (0.56 SEM) and $9.12 \mathrm{mg} \mathrm{O}_{2}$ $\mathrm{l}^{-1}$ (0.38 SEM) for shrimp treatments. On Day 2 mean oxygen levels were $5.48 \mathrm{mg} \mathrm{O}_{2} \mathrm{l}^{-1}(0.98 \mathrm{SEM})$ in noshrimp treatments and $6.78 \mathrm{mg} \mathrm{O} \mathrm{O}^{-1}(0.52 \mathrm{SEM})$ in shrimp treatments. Salinity was always $22 \%$. Mean temperature in the microcosms on Day 1 was $25.8^{\circ} \mathrm{C}$ $\left(0.024\right.$ SEM) and $26.3^{\circ} \mathrm{C}(0.026$ SEM) on Day 2 .

Copepods were the most abundant taxon sampled, making up $36 \%$ of the fauna on Spartina alterniflora stems with a mean of 978 per $100 \mathrm{~cm}^{2}$ across all experimental units (Table 3). Nematodes were second in abundance, comprising $35 \%$ of the fauna with a mean of 962 per $100 \mathrm{~cm}^{2}$. Copepod nauplii were the third most abundant taxon making up $28 \%$ of the fauna with a mean of 792 per $100 \mathrm{~cm}^{2}$. Other taxa collected from the stems included polychaetes, isopods, amphipods, tanaids, and mites, but these constituted $<1 \%$ of all

Table 3. Mean number of meiofaunal taxa ( \pm SEM) sampled from experimental treatments in the stem-predation experiment with overall mean and percent composition of each taxon. Values are reported as the number of individuals per $100 \mathrm{~cm}^{2}$ No-Shrimp: control treatments without grass shrimp Shrimp: treatments with grass shrimp added

\begin{tabular}{|lcccc|}
\hline Taxon & \multicolumn{2}{c}{ Treatment } & Mean & $\%$ \\
& No-Shrimp & Shrimp & & \\
\hline Nematoda & $1119(119.2)$ & $804(89.3)$ & 962 & 35 \\
Copepoda & $1268(137.2)$ & $688(80.3)$ & 978 & 36 \\
Nauplii & $1039(183.9)$ & $545(80.1)$ & 792 & 28 \\
\hline
\end{tabular}

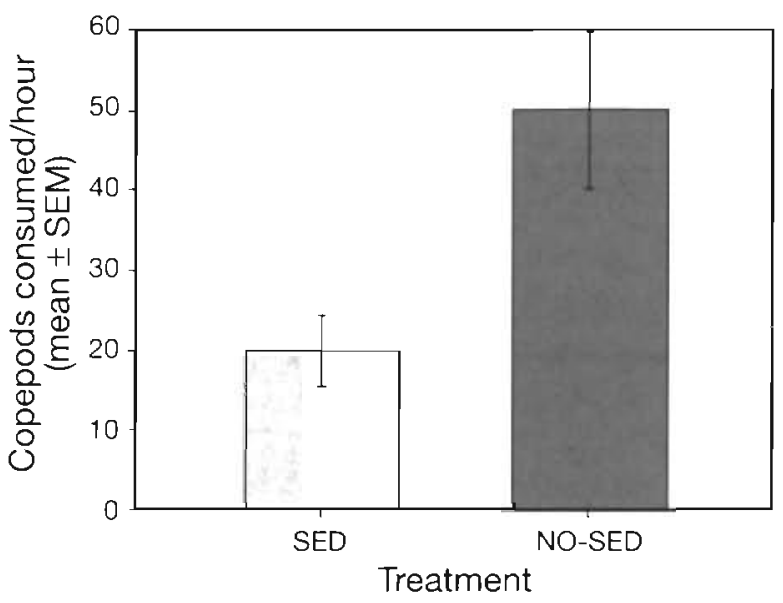

Fig. 2. Copepods consumed by grass shrimp in treatments with (SED) and without (NO-SED) a sediment substrate in 45 min feeding trials

fauna. Nematodes exhibited the greatest abundance on the lowest $6 \mathrm{~cm}$ section of stems $(0-6 \mathrm{~cm}=64 \%$, $6-12 \mathrm{~cm}=36 \%$ ), while copepod and copepod nauplius abundance was relatively equal over the lowest $12 \mathrm{~cm}$ of stems (copepods: $0-6 \mathrm{~cm}=48 \%, 6-12 \mathrm{~cm}=52 \%$; copepod nauplii: $0-6 \mathrm{~cm}=50 \%, 6-12 \mathrm{~cm}=50 \%$ ).

Grass shrimp consistently reduced meiofaunal density relative to no-shrimp controls (Table 3); reductions averaged $41 \%$. Results of the MANOVA showed significant treatment effects $\left(\lambda=0.781, F_{3,72}=6.74, \mathrm{p}=\right.$ 0.0005 ) from the lower $12 \mathrm{~cm}$ of Spartina alterniflora stems in grass shrimp treatments. Subsequent univariate analysis did not detect significant effects of grass shrimp on the abundance of nematodes $(F=2.71, \mathrm{p}=$ $0.1129)$ and copepod nauplii $(F=3.79, \mathrm{p}=0.063)$ over the bottom $12 \mathrm{~cm}$ of $S$. alterniflora stems. Significant reductions in the number of copepods in grass shrimp treatments were identified using ANOVA $(F=8.29, p=$ 0.0082 ). We also conducted MANOVAs on the $0-6 \mathrm{~cm}$ $\left(\lambda=0.696, F_{3,22}=3.20, \mathrm{p}=0.043\right)$ and $6-12 \mathrm{~cm}(\lambda=$ $0.720, F_{3,22}=2.85, p=0.061$ ) sections separately to determine if grass shrimp affected vertical profile of meiofauna on stems. In univariate analysis performed a posteriori, nematodes $(F=4.88, \mathrm{p}=0.037)$, copepods $(F=8.98, \mathrm{p}=0.0063)$, and copepod nauplii $(F=4.73, \mathrm{p}=$ $0.040)$ showed significant reductions in density on the $0-6 \mathrm{~cm}$ sections of $S$. alterniflora stems in grass shrimp treatments (Fig. 3a). Copepods were the only group that showed significant reductions in density on the $6-12 \mathrm{~cm}$ section of $S$. alterniflora stems $(F=5.95, \mathrm{p}=$ 0.023) (Fig. 3b). No significant shrimp effects were noted for nematodes $(F=0.29, p=0.59)$ or copepod nauplii $(F=2.25, \mathrm{p}=0.15)$ from the $6-12 \mathrm{~cm}$ stem section. When calculated across all taxa and stem sections, the reduction in meiofaunal abundance (an aver- 


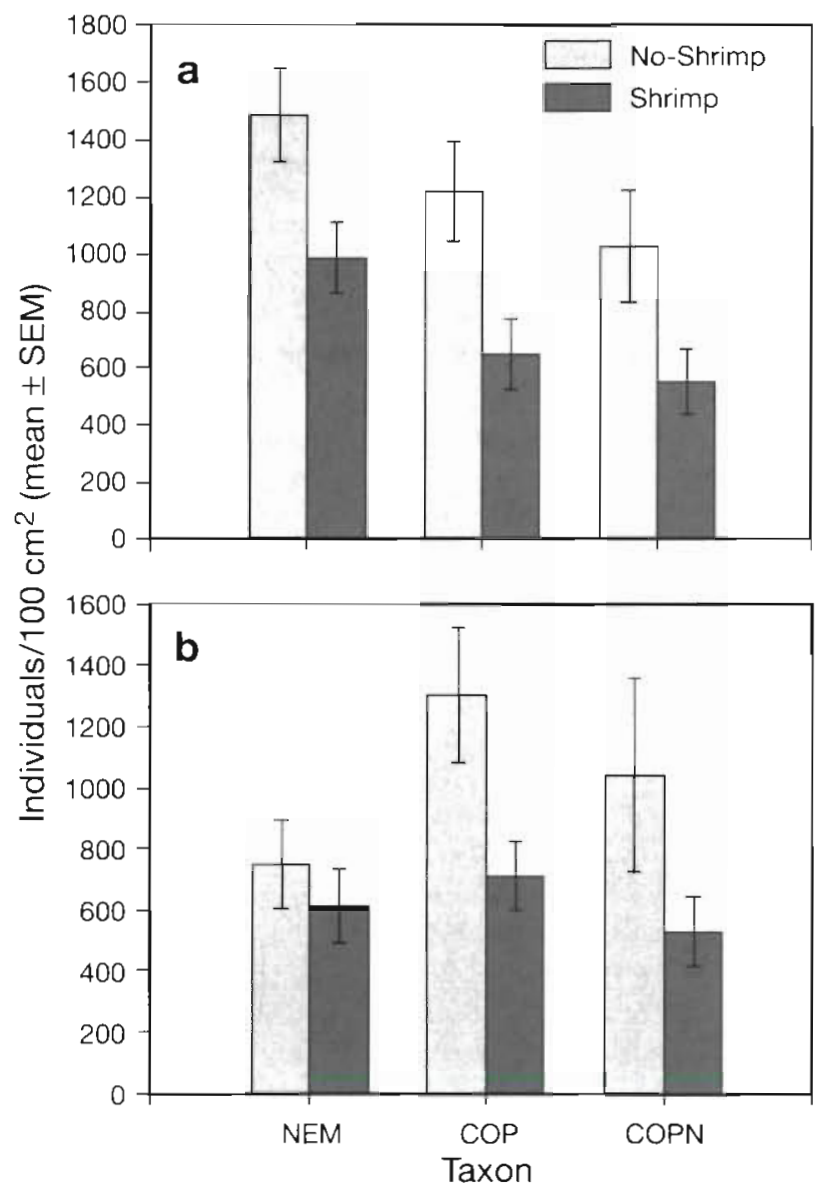

Fig. 3. (a) Mean density of meiofauna in various treatments for the $0-6 \mathrm{~cm}$ section of Spartina alterniflora stems at the end of the stem-predation experiment. (b) Mean density in various treatments for the $6-12 \mathrm{~cm}$ section of S. alterniflora stems at the end of the stem predation experiment. NEM: nematodes; COP: copepods; COPN: copepod nauplii; No-Shrimp: control treatments without grass shrimp; Shrimp: treatments with grass shrimp added

age of $41 \%$ in grass shrimp treatments) yielded an estimate of grass shrimp predation at 35 meiofauna $\mathrm{h}^{-1}$ shrimp $^{-1}$.

Qualitative samples taken from the substrate and water column in the microcosms revealed no significant difference between treatment in meiofaunal abundances in the sand substrate $(t=1.82, \mathrm{p}=0.11)$ or water column $(t=0.16, \mathrm{p}=0.88)$. Analyses of both sediment and water column samples indicated that some migration off of the stems occurred, but was equal in both treatments.

\section{DISCUSSION}

Our research suggests that Palaemonetes pugio is a very effective predator on meiofauna under specific conditions. When suspended copepods were offered to $P$. pugio, consumption rates reached a maximum of about $60 \mathrm{~h}^{-1}$ (a value similar to the maximum consumption rate by grass shrimp feeding on brine shrimp; Piyatiratitivorakul 1987). Although suspended copepods have not been shown to be a natural prey source for grass shrimp, copepods are frequently suspended into the near-bottom water and are important to the diet of a number of juvenile fishes (McCall \& Fleeger 1995). In addition, a laboratory experiment showed that meiofaunal densities on Spartina alterniflora stems were significantly reduced by grass shrimp (with shrimp densities about twice that expected in the field) in only $24 \mathrm{~h}$, yielding an estimated grass shrimp consumption rate of 35 meiofauna $\mathrm{h}^{-1}$ from stems. In laboratory feeding experiments, a sediment refuge reduced copepod consumption rates by $40 \%$ (compared to suspended copepods). Finally, field enclosures of grass shrimp did not result in reductions in density of infaunal or Spartina stem-associated meiofauna.

The utility of a combination of laboratory and field experiments to elucidate interactions in natural communities has frequently been suggested (Virnstein 1980, Diamond 1986), but such data are seldom available. For example, the study by Lipcius \& Hines (1986) is the only work known to us that measured the functional response of a predatory epibenthic crustacean. Our laboratory experiments provide the first measurements of the functional response of a predator using meiofauna as prey and the first comparisons of predation rates on meiofauna by the same predator but in different habitats. The relationship between resource density and feeding rate in aquatic and marine arthropods varies depending on habitat complexity and prey availability. Our results, that grass shrimp exhibit a type II functional response when feeding on suspended copepods, are comparable with measurements performed on other arthropod predators where habitat complexity does not inhibit feeding rate (Lampitt 1978. Lipcius \& Hines 1986). The carnivorous copepod Oithona nana exhibited a type II functional response while feeding on copepod nauplii contained in almost the same manner as in our experiment, i.e. prey suspended in water filled flasks (Lampitt 1978). In a substrate where their prey (Mya arenaria) could be easily extracted (sand), the blue crab Callinectes sapidus also showed a type II functional response (Lipcius \& Hines 1986). However, a mud substrate sufficiently inhibited blue crab predation when prey density was low, resulting in a type III functional response, and an implied refuge from predation for $M$. arenaria at low densities. While we did not measure the functional response of grass shrimp feeding on prey in a mud substrate, we noted similar decreases in feeding rate on harpacticoid 
copepods in our feeding efficiency experiments. Predation rates by grass shrimp decreased by $40 \%$, suggesting that sediments act as a refuge from predation for the copepod prey.

There were no significant reductions in density or alterations in vertical profile for any meiofaunal taxon on Spartina alterniflora stems in the $7 \mathrm{~d}$ stem-enclosure field experiment. In contrast, a laboratory experiment found significant declines in stem meiofaunal abundance, especially on the bottom $6 \mathrm{~cm}$ of stems, after only $24 \mathrm{~h}$. These contrasting results occurred even though both experiments were similarly implemented: 2544 meiofauna stem ${ }^{-1}$ in the field; 2331 meiofauna stem $^{-1}$ in the laboratory; 321 stems $\mathrm{m}^{-2}$ in both experiments; 225 shrimp $\mathrm{m}^{-2}$ in the field, 120 shrimp $\mathrm{m}^{-2}$ in the laboratory. The laboratory study estimated a consumption rate of 35 meiofauna $\mathrm{h}^{-1}$ shrimp $^{-1}$; a rate sufficient for grass shrimp to graze all meiofauna from the stems over $7 \mathrm{~d}$, which we did not observe. There are several possible explanations for these discrepancies.

Palaemonetes pugio has been classified as an omnivore (Odum \& Heald 1972, Morgan 1980), and in the field there is a wider array of food including detritus, sediment-dwelling meiofauna and small macrofauna, as well as benthic, epiphytic and planktonic algae. Prey switching by predators has been documented (Murdoch 1969, Akre \& Johnson 1979), and alternative prey can lessen the impact of predation on all prey, even the most preferred (Landenberger 1968, Fairweather 1987). Alternatively, meiofaunal densities in the field may have been replenished by colonization. Harpacticoid copepods, especially, are known to be passively eroded (or to make active forays) into the water column in response to flow conditions (Palmer \& Gust 1985, Palmer 1988), and the $1 \mathrm{~mm}$ mesh screen should not impede entrance into enclosures. Meiofaunal recruitment by settlement inside cages may even have been increased to levels above that in ambient sediments by a cage-induced alteration of flow. However, abundances of meiofauna in partial-cage controls were similar to no-cage control areas (in both field experiments) casting doubt on a hydrodynamically induced settlement of meiofauna, but not discounting the possibility of recruitment at background levels. Sediment-dwelling meiofauna may also migrate onto the stems during high tide (Palmer 1986). Finally, extreme physical factors (i.e. $\mathrm{O}_{2}$ levels, temperature, and salinity) influence predation rates (Stickle 1985, Piyatiratitivorakul 1987, Toepfer \& Fleeger 1995). Cages were located at an intertidal site where grass shrimp would have been exposed to a range of environmental conditions that might have reduced feeding ability.

Analyses of the vertical distribution of copepods on Spartina alterniflora stems in the laboratory experiment detected significant declines in nematodes, cope- pods and copepod nauplii on the $0-6 \mathrm{~cm}$ section; copepods were the only group reduced on the $6-12 \mathrm{~cm} \mathrm{sec}$ tion. Similar, but non-significant trends were noted for the field experiments on the $0-6 \mathrm{~cm}$ sections of $S$. alterniflora stems for non-interstitial copepods (those susceptible to predation). Meiofauna have been found in high numbers on the lower parts of $S$. alterniflora stem sheaths (Rutledge \& Fleeger 1993), and grass shrimp appear to concentrate their foraging activities on the lower stem sections (visual observation of the grass shrimp during the laboratory experiment revealed that they tended to remain close to the bottom of the aquaria). Grass shrimp are also known to be capable grazers on epiphytic algae (Morgan 1980), and it is likely that algae and meiofauna were consumed simultaneously from stems in our experiments.

Sediments have been shown to provide a refuge from predation for small macrofauna (Arnold 1984, Lipcius \& Hines 1986) because they offer a physically complex microhabitat (compared to the water column) that may effectively increase predator search and handling time. Grass shrimp did not affect the density of any meiofaunal taxon over $5 \mathrm{~d}$ in enclosures over nonvegetated sediments, perhaps as a result of similar reductions in feeding intensity. The laboratory experiment comparing grass shrimp consumption with and without sediment showed that sediment significantly reduced the feeding efficiency of grass shrimp by $40 \%$; a maximum of 20 copepods $\mathrm{h}^{-1}$ were consumed with sediment present. In the field experiment, enclosures contained approximately 225 grass shrimp $\mathrm{m}^{-2}$, and if each shrimp consumed 20 meiofauna $\mathrm{h}^{-1}$, then over $5 \mathrm{~d}$ the number of meiofauna consumed would be $2.9 \times 10^{5}$. Approximately $5.5 \times 10^{5}$ meiofauna were within the sediment enclosed by cages at the beginning of the experiment. If enclosures acted as a closed system, grass shrimp predation would have caused at least a $44 \%$ decline in meiofauna density (but no declines were observed). The effects of predation in softsediment communities is difficult to detect in field experiments because of extraneous variables which are difficult to control (Virnstein 1978, Peterson 1979). Artifacts caused by cage structure, such as reduction in disturbance (Dayton \& Oliver 1980) and hydrodynamic baffling of currents (Hulberg \& Oliver 1980), are always pitfalls in caging experiments. In addition, ecological processes might be responsible for the apparent lack of predation effects in the sediment-enclosure experiment. The patchiness of meiofauna in soft sediments is well known (Coull \& Bell 1979, Phillips \& Fleeger 1985, Sun \& Fleeger 1991) and, in this experiment, sample size was possibly insufficient (resulting in low power) to detect a significant change in meiofaunal abundance. Also, grass shrimp are known to produce positive indirect effects, or increased abun- 
dance in lower trophic levels, by negatively impacting infaunal predators (Kneib 1988, 1991).

This study demonstrates that variability in habitat types encountered by epibenthic predators influences their predation rates. The results indicated here, i.e. that predation rates on meiofauna change between marsh habitats, are comparable with the findings that demonstrate that substrate types affect the vulnerability of macrobenthic prey from macro-epibenthic predators (Lipcius \& Hines 1986). Our results also corroborate evidence demonstrating the importance of salt-marsh vegetation (i.e. Spartina alterniflora stems) as a habitat for prey of epibenthic grazers (Walters et al. 1996). Further work is clearly needed to determine how predation rates are influenced by habitat type as well as clarifying the role of Spartina stems in saltmarsh food webs.

Acknowledgements. We thank Donald Baltz, Kenneth Brown, and Kevin Carman for their helpful suggestions throughout this study. We especially thank Donald Baltz for the use of his cages, without which we could not have completed this work. We also thank the Louisiana Universities Marine Consortium (LUMCON) for the use of boats and laboratory facilities. Support from Louisiana Sea Grant (R/A-35-PD) during the period of this study is also appreciated. C.G. is especially indebted to $\mathrm{J}$. Gregg for her unending support and patience.

\section{LITERATURE CITED}

Akre BG, Johnson DM (1979) Switching and sigmoid functional response curves by damselfly naiads with alternative prey available. J Anim Ecol 48:703-720

Arnold WS (1984) The effect of prey size, predator size, and sediment composition on the rate of predation of the blue crab, Callinectes sapidus Rathbun, on the hard clam, Mercenaria mercenaria (Linne). J Exp Mar Biol Ecol 80: $207-219$

Bell SS (1980) Meiofauna-macrofauna interactions in a high salt marsh habitat. Ecol Monogr 50:487-505

Bell SS, Coull BC (1978) Field evidence that shrimp predation regulates meiofauna. Oecologia 35:141-148

Bell SS, Waiters K. Hall MO (1987) Habitat utilization by harpacticoid copepods: a morphometric approach. Mar Ecol Prog Ser 35:59-64

Burke WW (1976) Vertical and horizontal distribution of macroinvertebrates on the cordgrass, Spartina alterniflora, in a Louisiana salt marsh. MS thesis, Louisiana State University, Baton Rouge

Coull BC (1977) Marine flora and fauna of the Northeastern United States. Copepoda: Harpacticoida. NOAA Technical Report, NMFS Circular 399, p 1-48

Coull BC, Bell SS (1979) Perspectives in marine meiofaunal ecology. In: Livingston RJ (ed) Processes in coastal and marine systems. Plenum Press, New York

Coull BC, Palmer MA, Myers PE (1989) Controls on the vertical distribution of meiobenthos in mud: field and flume studies with juvenile fish. Mar Ecol Prog Ser 55:133-139

Coull BC, Greenwood JG, Fielder DR, Coull BA (1995) Subtropical Australian juvenile fish eat meiofauna: experiments with winter whiting Sillago maculata and observa- tions on other species. Mar Ecol Prog Ser 125:13-19

Dayton PK, Oliver JS (1980) An evaluation of experimental analysis of population and community patterns in benthic marine environments. In: Tenore KR, Coull BC (eds) Marine benthic dynamics. University of South Carolina Press, Columbia, p 93-120

Decho AW, Fleeger JW (1988) Ontogenetic feeding shifts in the meiobenthic harpacticoid copepod Nitocra lacustris. Mar Biol 97:191-197

Diamond J (1986) Overview: laboratory experiments, field experiments, and natural experiments. In: Diamond $\mathrm{J}$, Case TJ (eds) Community ecology. Harper \& Row, New York, p 3-22

Ellis MJ, Coull BC (1989) Fish predation on meiobenthos: field experiments with juvenile spot Leiostomus xanthurus Lacepede. J Exp Mar Biol Ecol 130:19-32

Fairweather PG (1987) Experiments on the interaction between predation and the availability of different prey on rocky seashores. J Exp Mar Biol Ecol 114:261-273

Fitzhugh GR, Fleeger JW (1985) Goby (Pisces: Gobiidae) interactions with meiofauna and small macrofauna. Bull Mar Sci 36:436-444

Fleeger JW (1985) Small benthos in estuarine food webs: comparing intertidal and subtidal habitats. In: Bryan $\mathrm{CF}_{\text {, }}$ Zwank PJ, Chabreck RH (eds) Proceedings of the fourth coastal marsh and estuary management symposium. Louisiana Cooperative Fishery Research Unit, Baton Rouge, p $127-141$

Fleeger JW, Chandler GT (1983) Meiofauna responses to an experimental oil spill in a Louisiana salt marsh. Mar Ecol Prog Ser 11:257-264

Fleeger JW, Yund PO, Sun B (1995) Active and passive processes associated with initial settlement and postsettlement dispersal of suspended meiobenthic copepods J Mar Res 53:609-645

Gee JM (1987) Impact of predation on estuarine intertidal harpacticoid copepods populations. Mar Biol 96:497-510

Gee JM, Warwick RM, Davey JT, George GL (1985) Field experiments on the role of epibenthic predators in determining prey densities in an estuarine mudflat. Estuar Coast Shelf Sci 21:429-448

Hayden WHF (1994) Microhabitat use by macroinvertebrates in the Barataria Bay, Louisiana. MS thesis, Louisiana State University, Baton Rouge

Heally B, Walters K (1994) Oligochaeta in Spartina stems: the microdistribution of Enchytridae and Tubificidae in a salt marsh, Sapelo Island, USA. Hydrobiologia 278:111-123

Hedquist-Johnson K. Andre C (1991) The impact of the brown shrimp, Crangon crangon L., on soft-bottom meiofauna: an experimental approach. Ophelia 34:41-49

Hulberg LW, Oliver JS (1980) Caging manipulations in softbottom communities: importance of animal interactions or sedimentary habitat modifications. Can J Fish Aquat Sci 37:1130-1139

Ivlev VS (1961) Experimental ecology and feeding of fishes (D. Scott, translator). Yale University

Juliano SA (1993) Nonlinear curve fitting: predation and functional response curves. In: Shiener SM, Gurevitch J (eds) Design and analysis of ecological experiments. Chapman and Hall, New York, p 159-182

Kneib RT (1985) Predation and disturbance by grass shrimp. Palaemonetes pugio Holthius, in soft-substratum benthic invertebrate assemblages. J Exp Mar Biol Ecol 93:91-102

Kneib RT (1988) Testing for indirect effects of predation in an intertidal soft-bottom community. Ecology 69:1795-1805

Kneib RT (1991) Indirect effects in experimental studies of marine soft-sediment communities. Am Zool 31:874-885 
Lampitt RS (1978) Carnivorous feeding by a small marine copepod. Limnol Oceanogr 23:1228-1231

Landenberger DE (1968) Studies on selective feeding in the Pacific starfish Pisaster in Southern California. Ecology 49 1002-1075

Lipcius RN, Hines AH (1986) Variable functional response of a marine predator in dissimilar homogeneous habitats. Ecology 67:1361-1371

McCall JN, Fleeger JW (1995) Predation by juvenile fish on hyberbenthic meiofauna: a review with data on post-larval Leiostomus xanthurus. Vie Milieu 45:61-73

Morgan MD (1980) Grazing and predation of the grass shrimp Palaemonetes pugio. Limnol Oceanogr 25:896-902

Murdoch WW (1969) Switching in general predators: experiments on predator specificity and stability of prey populations. Ecol Monogr 39:335-354

Nilsson P. Sundback K. Johnson B (1993) Effect of the brown shrimp, Crangon crangon L., on endobenthic macrofauna, meiofauna, and meiofaunal grazing rates. Neth J Sea Res $31: 95-106$

Odum WE, Heald EJ (1972) Trophic analysis of an estuarine mangrove community. Bull Mar Sci 22:671-738

Olafsson E, Moore CG (1990) Control of meiobenthic abundance by macroepifauna in a subtidal muddy habitat. Mar Ecol Prog Ser 65:241-249

Olafsson E, Moore CG (1992) Effects of macrofauna on developing nematode and harpacticoid assemblages in a subtidal muddy habitat. Mar Ecol Prog Ser 84:161-171

Olafsson EB, Peterson CH. Ambrose WG (1994) Does recruitment limitation structure populations and communities of macro-invertebrates in marine soft sediments: the relative significance of pre- and post-settlement processes Oceanogr Mar Biol Annu Rev 32:65-109

Palmer MA (1986) Hydrodynamics and structure: interactive effects on meiofauna dispersal. J Exp Mar Biol Ecol 104 : 53-68

Palmer MA (1988) Epibenthic predators and marine meiofauna: separating predation, disturbance, and hydrodynamic effects. Ecology 69:1251-1259

Palmer MA, Gust G (1985) Dispersal of meiofauna in a turbulent tidal creek. J Mar Res 43:179-210

Peterson CH (1979) Predation, competitive exclusion, and diversity in the soft sediment benthic communities of estuaries and lagoons. In: Livingston RJ (ed) Ecological processes in coastal and marine systems. Plenum Press, New

Editorial responsibility: William B. Stickle Jr (Contributing Editor), Baton Rouge, Louisiana, USA
York, p 233-264

Phillips FE, Fleeger JW (1985) Meiofauna meso-scale variability in two estuarine habitats. Estuar Coast Shelf Sci 21: $745-756$

Plyatiratitivorakul S (1987) The life history and bioenergetics relations in the grass shrimp. Palaemonetes pugio Holthius. $\mathrm{PhD}$ dissertation, University of South Carolina, Columbia

Rutledge PA, Fleeger JW (1993) Abundance and seasonality of meiofauna, including harpacticoid copepod species, associated with stems of the salt-marsh cord grass, Spartina alterniflora. Estuaries 16:760-768

SAS Institute, Inc (1985) SAS users guide: statistics, version 6.03. SAS Institute, Inc, Cary, NC

Smith LD, Coull BC (1987) Juvenile spot (Pisces) and grass shrimp predation on meiobenthos in muddy and sandy substrates. J Exp Mar Biol Ecol 105:123-136

Stickle WB (1985) Effects of environmental factor gradients on scope for growth in several species of carnivorous marine invertebrates. In: Gray JS, Christiansen ME (eds) Marine biology of polar regions and effects of stress on marine organisms. John. Wiley \& Sons Ltd, Chichester, p 601-616

Sun B, Fleeger JW (1991) Spatial and temporal patterns of dispersion in meiobenthic copepods Mar Ecol Prog Ser $71: 1-11$

Sun B, Fleeger JW (1995) Sustained mass culture of Amphiascoides atopus, a marine harpacticoid copepod in a recirculating system. Aquaculture 136:313-321

Toepfer CS, Fleeger JW (1995) Influences of the marsh edge on juvenile Bay Whiff, Citharichthys spilopterus (Teleostei:Bothidae). Southwest Nat 40:297-300

Trexler JC, McCulloch CE, Travis J (1988) How can the functional response best be determined? Oecologia 76 : 206-214

Van Dolah RF (1978) Factors regulating the distribution and population dynamics of the amphipod Gammarus palustris in an intertidal salt marsh. Ecol Monogr 48:191-217

Virnstein RW (1978) Predator caging experiments in soft sediments: caution advised. In: Wiley ML (ed) Estuarine interactions. Academic Press, New York, p 261-273

Virnstein RW (1980) Measuring effects of predation on benthic communities in soft sediments. In: Kenedy VS (ed) Estuarine perspectives. Academic Press, New York, p 281-291

Walters K, Jones E, Etherington L (1996) Experimental studies of predation on metazoans inhabiting Spartina alterniflora stems. J Exp Mar Biol Ecol 195:251-265

Submitted: February 17, 1997; Accepted: May 26, 1998 Proofs received from author(s): November 16, 1998 